DOI

\title{
ВИКЛАДАННЯ ДИСЦИПЛІН НА КАФЕДРІ ФІЗИЧНОЇ РЕАБІЛІТАЦЇ,, ЗДОРОВ’Я ЛЮДИНИ ТА ФІЗИЧНОГО ВИХОВАННЯ ЗА НАПРЯМОМ ПІДГОТОВКИ “ЗДОРОВ’Я ЛЮДИНИ”
}

\author{
Д. В. Козак, Н. О. Давибіда
}

ДВНЗ “Тернопільський державний медичний університет імені І. Я. Горбачевського МОЗ України”

\section{TEACHIING SUBJECTS AT THE DEPARTMENT OF PHYSICAL REHABILITATION, HUMAN HEALTH AND PHYSICAL TRAINING IN THE DIRECTION OF "HUMAN HEALTH"}

\author{
D. V. Kozak, N. O. Davybida \\ SHEI "Ternopil State Medical University by I. Ya. Horbachevsky of MPH of Ukraine”
}

\begin{abstract}
Реабілітація є одним із основних напрямків у системі охорони суспільного здоров'я і включає державні, соціальноекономічні, психологічні, медичні, професійні, педагогічні та інші заходи, що спрямовані на лікування та попередження захворювань. На даний час в державі відсутня система підготовки спеціалістів з фізичної реабілітації з вищою медичною освітою, які могли б надати кваліфіковану медичну допомогу хворим для досягнення ними максимальної фізичної повноцінності. Сьогодні окремі функції з фізичної реабілітації виконують лікарі-фізіотерапевти та лікарі $з$ лікувальної фізкультури. Але це не відповідає сучасним вимогам до фахівця з фізичної реабілітації.

Rehabilitation is one of the key areas in health and social care including state, socio-economic, psychological, medical, professional, educational and other measures aimed at treatment and prevention of diseases. Currently there is no state system of training specialists in physical rehabilitation with higher medical education that could provide quality medical care for patients reaching the maximum of faculty. Today, some functions perform physical rehabilitation doctors and physiotherapists, doctors of physical therapy. But it does not meet modern requirements to a specialist in physical rehabilitation.
\end{abstract}

Вступ. На кафедрі фізичної реабілітації, здоров’я людини та фізичного виховання студенти навчаються уміння використовувати в конкретних ситуаціях знання про реабілітаційне обстеження, забезпечувати процеси фізичної реабілітації, психічне, фізичне та соціальне здоров'я людини, надавати комплексну оцінку індивідуальним особливостям у процесі оздоровлення, видам оздоровчо-рекреаційної рухової активності, принципам здорового способу життя серед населення. На сучасному етапі дисципліни, які викладаються на кафедрі, мають велике практичне значення для якісної всебічної підготовки майбутніх фахівців з фізичної реабілітації. Особливо з питань, що стосуються використання засобів фізичної культури і фізичної реабілітації для профілактики захворювань, швидкого відновлення здоров'я, збереження якості життя та попередження або ліквідації різних ускладнень у хворих. Найбільш активним, цілеспрямованим і

() Д. В. Козак, Н. О. Давибіда дієвим засобом фізичної реабілітації є лікувальна фізична культура (ЛФК) - метод відновного лікування, [2, 3], який не має рівноцінних аналогів за своїм природно-біологічним впливом, завдяки чому саме він відіграє головну роль серед інших немедикаментозних відновних та профілактичних заходів. Недооцінка і недостатнє або несвоєчасне застосування засобів фізичної реабілітації в комплексному лікуванні хворих [6] часто призводить до суттєвого збільшення термінів їх одужання, виникнення важких ускладнень, і навіть до стійкої втрати працездатності. ЛФК й інші фізичні чинники повинні бути не додатковими засобами, а невід'ємною складовою комплексного лікування протягом усіх періодів реабілітації [1, 4].

Проведення ефективного відновного лікування потребує від реабілітологів вміння оцінювати функціональний стан основних фізіологічних систем організму та функціональні розлади систем у хворих, а також здійснювати вибір найбільш ефективних засобів фізичної реабілітації з урахуванням 
клінічного перебігу захворювання (фази, стадії, ступеня функціональних розладів системи), супутньої патології, а також відповідно до індивідуальних особливостей організму (віку, статі, функціональних здібностей, рівня фізичної підготовленості та толерантності до фізичних навантажень, стану захисних систем) [5]. Не менш важливим є використання засобів фізичної культури і реабілітації для профілактики або функціонального лікування професійних захворювань у лікарів, особливо це стосується порушень постави, сколіозу, остеохондрозу хребта, варикозного розширення вен нижніх кінцівок, захворювань системи кровообігу, органів дихання та іншої патології. Отже, якісна підготовка реабілітологів неможлива без досконалого оволодіння основами фізичної реабілітації і спортивної медицини.

Основна частина. Викладачі кафедри здійснюють підготовку майбутніх фахівців реабілітаційної галузі до високопродуктивної праці, зміцнення здоров’я, а також формування професійних знань, вмінь та навиків під час використання фізичної культури в профілактичній та лікувальній діяльності відповідно до концепції розвитку університету, постійно працюють над удосконаленням навчального процесу, в тому числі з використанням новітніх навчальних та інноваційних методик і програм, оновлюють відповідні розділи в системі Moodle, що відображають сучасний розвиток реабілітаційних технологій.

На кафедрі викладається 21 навчальна дисципліна за системою єдиного дня: для студентів медичного факультету за напрямком підготовки “Здоров’я людини” на 1 курсі викладаються такі дисципліни: вступ до спеціальності, види оздоровчо-рекреаційної рухової активності, фізичне виховання.

Метою викладання цих дисциплін є ознайомлення студентів з галуззю їхньої майбутньої професійної діяльності та закладення фундаменту для засвоєння матеріалу з інших навчальних дисциплін за професійним спрямуванням “Фізична реабілітація”. Це обумовлює змістове наповнення дисципліни та структурну організацію її викладання. Вивчення цих дисциплін протягом навчання у ВНЗ це визначення основних термінів, пов’язаних зі сферою їх професійної діяльності, основи професійних вимог, стандартів і етичних норм, принципи ведення медичної документації, основні правила спілкування з пацієнтом, принципи правильного переміщення пацієнта, принципи підбору технічних засобів допомоги для пересування, основні принципи проведен- ня пасивних і активних вправ з пацієнтом, правила вимірювання та контролю за основними життєвими показниками, основні принципи інфекційного контролю, правила надання першої медичної допомоги, принципи адаптації навколишнього середовища до потреб неповносправних.

Дисципліни, які вивчаються на 2 курсі за напрямком підготовки “Здоров’я людини”: фізичне виховання, основи здорового способу життя, загальна теорія здоров'я, основи фізичної реабілітації, масаж загальний і самомасаж; теорія і методика фізичного виховання; теорія і технологія оздоровчорекреаційної рухової активності; методика навчання основ здоров'я; види оздоровчо-рекреаційної рухової активності. Метою викладання даних навчальних дисциплін $є$ оволодіння теоретичними основами та практичними навичками управління фізичним здоров’ям людини. Завданням даних дисциплін є формування здорового способу життя - всі його сторони і прояви, які позитивно впливають на здоров'я. Значить, немає такого виду, способу активності, діяльності, які б у своїх позитивних проявах не формували здоровий спосіб життя. Значить, у діяльності щодо охорони і поліпшення здоров'я населення, в гігієнічному вихованні, потрібно враховувати розмаїття впливів, умов та факторів, що визначають характер і рівень здоров’я людини, групи людей і населення. Виходячи з концепції здорового способу життя, реабілітолог сьогодні повинен бути орієнтований не тільки на патологію, але й займатися профілактикою захворювань, тобто здоров’ям здорової людини. Випускник медичного вищого навчального закладу (ВНЗ) на сучасному етапі повинен стати пропагандистом формування престижності здоров'я і впровадження фізкультури в спосіб життя всіх верств населення. Медичні ВНЗ повинні готувати всебічно розвинених спеціалістів, які б володіли теоретичними знаннями і практичними навичками та вміннями застосування різноманітних засобів фізичної культури й масажу у своїй оздоровчо-профілактичній роботі. Тільки так можна зберегти здоровий генофонд країни.

У зв’язку з цим дані дисципліни повинні стати пріоритетними дисциплінами при підготовці фахівців з фізичної реабілітації.

Дисципліни, які вивчаються на 3 курсі за напрямком підготовки “Здоров’я людини”: діагностика і моніторинг стану здоров’ я; онтокінезіологія; масаж реабілітаційний; теорія і методика спортивної підготовки; історія спортивного та олімпійського руху; спортивна медицина. 
Забезпечення послідовності та взаємозв'язку 3 анатомією людини, медичною біологією, медичною хімією, медичною та біологічною фізикою, фізіологією, патофізіологією, гігієною та екологією, фармакологією, пропедевтикою внутрішньої медицини, хірургією, травматологією й ортопедією, неврологією, педіатрією, акушерством і гінекологією та іншими предметами навчального плану, що передбачає інтеграцію викладання з даними дисциплінами та формування умінь застосування знань у процесі подальшого навчання й у професійній діяльності.

Ціль навчального процесу на кафедрі - навчити студентів застосовувати засоби фізичної культури й інші фізичні чинники в професійній практиці для забезпечення профілактики захворювань, а також для більш швидкого відновлення здоров'я, якості життя і працездатності у хворих і забезпечити попередження передпатологічних змін та патологічних станів, які виникають при нераціональному застосуванні фізичної активності. Дані дисципліни на сучасному етапі набувають все більшого значення для якісної всебічної підготовки майбутніх реабілітологів. Особливо з питань, що стосуються збереження і зміцнення здоров’я людей, покращення якості їх життя та забезпечення активного творчого довголіття шляхом оптимізації рухової активності, а також більш швидкого відновлення здоров'я і працездатності хворих різноманітного профілю за допомогою фізичної реабілітації. Досвід впровадження оптимальної рухової активності в спосіб життя громадян економічно розвинутих країн світу та своєчасна, ефективна фізична реабілітація при захворюваннях свідчать про можливості істотно зменшувати витрати держави на систему охорони здоров'я, ліки та звернення населення за повторною медичною допомогою. У зв'язку із зазначеним засоби фізичної культури і спорту починають займати ведуче місце в системі превентивної медицини та відновного лікування. Проте найважливіша в соціальному плані профілактична й оздоровча функція фізичної культури і спорту, а також максимальний позитивний ефект при фізичній реабілітації можуть бути досягнуті лише за умов раціональної системи занять фізичними вправами, що, у свою чергу, залежить від кваліфікованого медичного контролю за здоров'ям тих, хто займається. При цьому слід враховувати, що якщо медичний контроль за провідними спортсменами здійснюють в основному лікарсько-фізкультурні диспансери або центри спортивної медицини і лікувальної фізкультури, то медичне забезпечення в оздоровчій фізичній культурі, масовому спорті та при фізичній реабілітації покладено, перш за все, на лікувально-профілактичні установи за місцем проживання, праці чи навчання. Саме тому лікарі загальної практики, сімейні лікарі, педіатри, лікарі вузьких спеціальностей та інші фахівці повинні орієнтуватись у важливих питаннях, пов'язаних із допуском до занять фізичними вправами різних груп населення, володіти засобами й методами медичного (лікарського) контролю за тими, хто займається, знати показання та протипоказання до застосування сучасних засобів фізичної реабілітації при різних захворюваннях та ушкодженнях, мати уявлення про ускладнення і патологічні стани, що виникають при неадекватних фізичних навантаженнях, володіти методами їх своєчасної діагностики, профілактики та лікування.

Підготовка студентів медичного факультету за напрямком підготовки “Здоров”я людини” включає:

- теоретичну та практичну підготовки з акцентом на медико-біологічні дисципліни в обсязі програмного матеріалу, що вивчається у процесі теоретичних і практичних занять;

- спеціальну підготовку в процесі практичних занять в умовах клініки, а також ознайомчої, тренерської та переддипломної практик;

- інструкторсько-методичну підготовку спеціалістів у межах програмного матеріалу, викладеного в методичних рекомендаціях кафедр;

- професійну підготовку в межах програмного матеріалу, викладеного у робочих програмах (загальний курс, спеціалізація);

- організаційно-управлінську підготовку;

- науково-методичну підготовку, що спрямована на оволодіння знаннями, вміннями та навичками, що достатні для сумісного з лікарем планування, організації, проведення обліку та контролю ефективності програм фізичної реабілітації на всіх етапах відновлення здоров'я, працездатності та спеціальної працездатності, забезпечення психологічної підтримки; діяльності з первинної профілактики захворювань на підставі пропаганди здорового способу життя та усунення чинників ризику, для діяльності з фізичної рекреації, планування навчально-тренувального процесу, самостійних занять, розвитку фізичних якостей, інструкторськометодичних знань, умінь та навичок з вивчення ефективних методів і засобів реабілітації, у тому числі біотехнічних, навчання та тренування, самостійних завдань, контрольних нормативів, відбору та професійної орієнтації; 
- психологічну підготовку та знання медичної етики, психології і деонтології в обсязі вимог, які необхідні для роботи з хворими та травмованими;

- психологічну та функціональну підготовку в обсязі вимог, що пред’являються рівнем спеціальної спортивної майстерності психофізичних функцій;

- професійно-педагогічну підготовку рекомендацій у процесі проведення усіх форм занять, фізкультурно-масових, оздоровчих, профілактичних і спортивних заходів;

- професійно-прикладну фізичну підготовку, психологічну підготовку, яка реалізується спеціально підібраними засобами та методами.

Викладачами кафедри на WEB-порталі університету розміщено необхідні матеріали в системі Moodle (робочі програми, методичні вказівки, матеріали підготовки до лекцій та презентації лекцій, матеріали підготовки до практичних занять, тестовий контроль знань у системі Moodle) для засвоєння дисциплін, які викладаються.

Висновок. Метою викладання дисциплін на кафедрі фізичної реабілітації, здоров’я людини та фізичного навантаження $є$ навчання студентів оволодівати методами фізичної реабілітації хворих з постійною та тимчасовою втратою працездатності,

\section{Список літератури}

1. Лікувальна фізкультура та спортивна медицина : підручник / [В. В. Клапчук, Г. В. Дзяк, І. В. Муравов та ін.] ; за ред. В. В. Клапчука, Г. В. Дзяка. - К. : Здоров’я, 2005. - 312 c.

2. Лікувальна фізкультура та спортивна медицина: вибрані лекції для студентів / [В. В. Абрамов, В. В. Клапчук, О. Л. Смирнова та ін.] ; за ред. проф. В. В. Клапчука. - Дніпропетровськ : Медакадемія, 2006. - 179 с.

3. Мухін В. М. Фізична реабілітація / В. М. Мухін. 3-тє вид., переробл. та доповн. - К. : Олімпійська література, 2009. - 488 с.

4. Марченко О. К. Фізична реабілітація хворих із травмами й захворюваннями нервової системи : навч. сприяти відновленню їх працездатності та поверненню їх до активного суспільного життя і соціально корисної праці. Поглибити загальнобіологічну і методичну підготовку спеціалістів з фізичної реабілітації. Сформувати у студентів знання про: зміст, завдання, види реабілітації; організаційні основи процесу реабілітації, основні засоби реабілітації; фізичну реабілітацію, характеристику ї̈ засобів; методи та правила застосування фізичних методів реабілітації. Поглибити знання з анатомофізіологічних особливостей окремих ділянок тіла, серцево-судинної, дихальної, нервової, травної та ін. систем, i, на основі отриманих знань та навичок з основ фізичної реабілітації, навчити проводити фізичну реабілітацію хворих. Підготувати студентів до науково обгрунтованого проведення занять лікувальної фізкультури, праце- та механотерапії хворим на різних етапах відновного лікування. Навчити студентів проводити заняття лікувальної фізкультури, працетерапії, механотерапії в поєднанні з масажем та іншими методами фізичної реабілітації. Підготувати студентів до вивчення інших дисциплін і використання засобів фізичної реабілітації в реабілітаційному процесі хворих та спортсменів.

посіб. / О. К. Марченко. - К. : Олімпійська література, 2006. - 196 c.

5. Полянська О. С. Основи реабілітації, фізіотерапії, лікувальної фізичної культури і масажу / О. С. Полянська; за ред. В. В. Клапчука, О. С. Полянської. - Чернівці : Прут, 2006. - 208 с.

6. Романчук О. П. Лікарсько-педагогічний контроль в оздоровчій фізичній культурі : навч.-метод. посіб. / О. П. Романчук. - Одеса : Видавець Букаєв Вадим Вікторович, 2010. - 206 с.

Отримано 03.06.15 